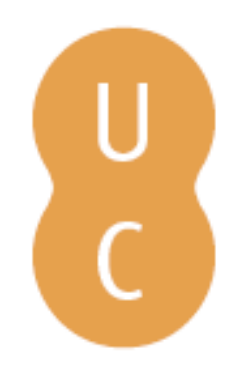

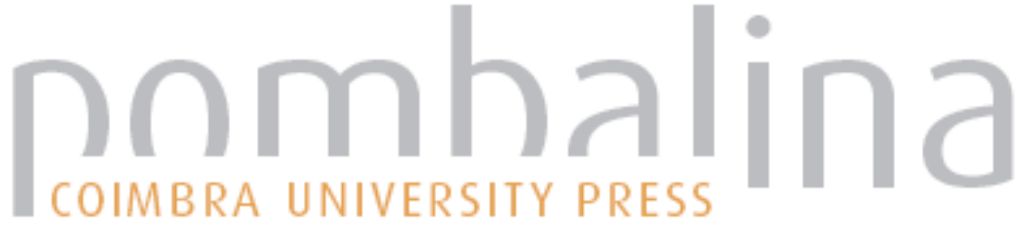

\section{Antígona, o fruto de uma cepa deformada: Hélia Correia, Perdição}

Autor(es): $\quad$ Silva, Maria de Fátima

Publicado por: Imprensa da Universidade de Coimbra

URL

persistente: URI:http://hdl.handle.net/10316.2/32313

DOI: $\quad$ DOI:http://dx.doi.org/10.14195/978-989-26-0391-9_2

Accessed : $\quad$ 26-Apr-2023 15:12:12

A navegação consulta e descarregamento dos títulos inseridos nas Bibliotecas Digitais UC Digitalis, UC Pombalina e UC Impactum, pressupõem a aceitação plena e sem reservas dos Termos e Condições de Uso destas Bibliotecas Digitais, disponíveis em https://digitalis.uc.pt/pt-pt/termos.

Conforme exposto nos referidos Termos e Condições de Uso, o descarregamento de títulos de acesso restrito requer uma licença válida de autorização devendo o utilizador aceder ao(s) documento(s) a partir de um endereço de IP da instituição detentora da supramencionada licença.

Ao utilizador é apenas permitido o descarregamento para uso pessoal, pelo que o emprego do(s) título(s) descarregado(s) para outro fim, designadamente comercial, carece de autorização do respetivo autor ou editor da obra.

Na medida em que todas as obras da UC Digitalis se encontram protegidas pelo Código do Direito de Autor e Direitos Conexos e demais legislação aplicável, toda a cópia, parcial ou total, deste documento, nos casos em que é legalmente admitida, deverá conter ou fazer-se acompanhar por este aviso. 
Maria de Fátima Sousa e Silva

Coordenação

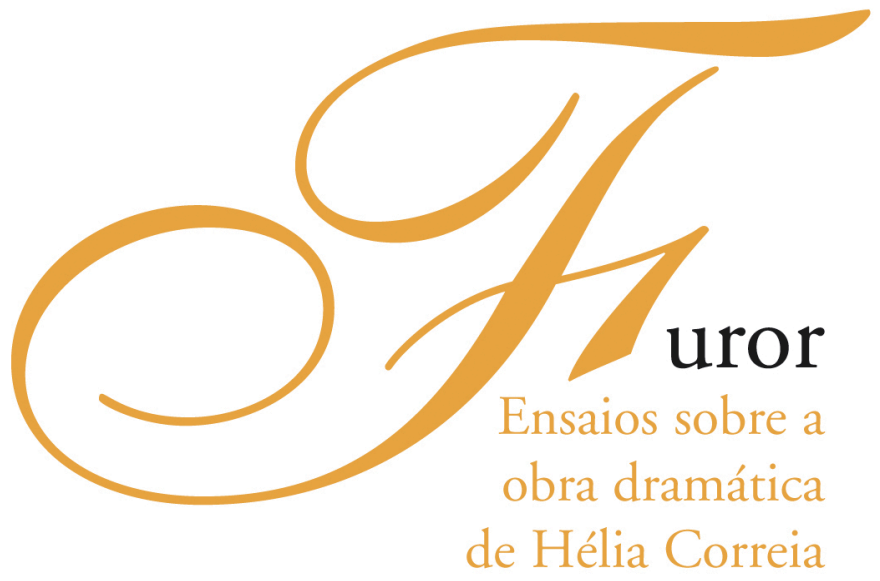

- COIMBra 2006 
COORDENAÇÃO EDITORIAL

Imprensa da Universidade de Coimbra

URL: http//www.imp.uc.pt

\author{
CONCEPÇÃO GRÁFICA \\ António Barros \\ PAGINAÇÃO \\ Inova \\ EXECUÇÃO GRÁFICA \\ Inova - Artes Gráficas \\ Porto
}

ISBN

972-8704-94-1

DEPÓSITO LEGAL

247166/06

C OUTUBRO, 2006, IMPRENSA DA UNIVERSIDADE DE COIMBRA

OBRA PUBLICADA COM O APOIO DE:

Centro de Estudos Clássicos e Humanísticos

FCT Fundação para a Ciência e a Tecnologia

MINISTÉRIO DA CIÊNCIA, TECNOLOGIA E ENSINO SUPERIOR Portugal 
Maria de Fátima Sousa e Silva

Coordenação

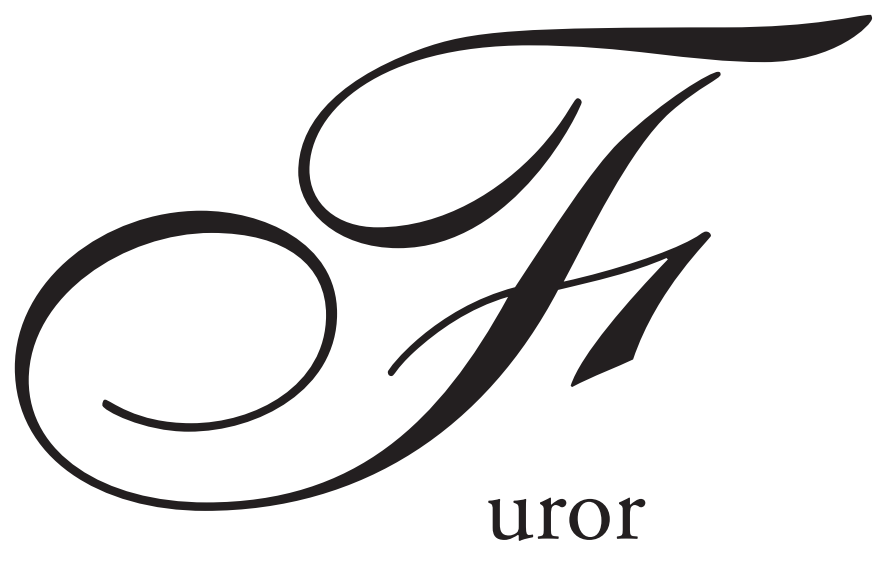

\author{
Ensaios sobre a \\ obra dramática \\ de Hélia Correia
}



Maria de Fátima Silva

Universidade de Coimbra

\section{ANTÍGONA, O FRUTO DE UMA CEPA DEFORMADA HÉLIA CORREIA, PERDIÇÃO*}

A concepção inovadora de Perdição de Hélia Correia sugere, para além de um contraste evidente com o original, a conclusão da diversidade de leituras que as mesmas fontes proporcionam. Tudo é anticonvencional na produção de Hélia, embora uma leitura atenta do texto sofocliano seja indesmentível sob as novas opções. Mas quer na interpretação temática, como na arquitectura formal, cada pormenor é agora distinto. As informações prévias, que se constituem da lista das personagens e de um enunciado sobre os planos em que a acção se desenvolve, desde logo o anunciam. Ao nome de Antígona, como protagonista incontestada, sucede-se a menção da Ama de Antígona, de Eurídice e Isménia, relegados para depois os nomes de Hémon, Creonte e os das figuras menores do Criado, do Mensageiro e dos Guardas. O reforço da galeria feminina, acrescida de uma Ama de papel preponderante na peça, como o destaque que lhe é dado nesta listagem inicial, criam uma imediata sensação da preponderância deste elemento. Uma nova proporção parece estabelecida entre o masculino e o feminino, além de que a presença da Ama, no circuito mulheril que rodeia Antígona, deixa no ar um tom mais pessoal e íntimo a cercar a heroína; no texto, uma ambiguidade evidente na natureza desta figura, uma espécie de mão do destino ou daimon, ir-se-á consolidando. No fim do elenco anunciado, regista-se ainda a menção de Antígona e da Ama mortas, e de Tirésias. Da surpresa

\footnotetext{
* Este texto foi antes publicado em Máscaras Portuguesas de Antigona, coord. Carlos Morais, Aveiro, 2001, pp. 103-118.
} 
criada por esta síntese, se passa a uma necessária definição dos três planos da acção: o de "Tirésias, o adivinho e cego, muito velho, que preside e comenta os acontecimentos, longe do local da acção»; «um pátio do palácio de Tebas e depois a sala do trono. Aí se desenrolam os diálogos dos vivos»; «um campo de asfódelos na penumbra. As mortas devem atravessá-lo, perdendo cada vez mais a luz e a relação entre elas». Uma palavra preambular merece ainda à autora a componente musical / coro: «um hino a Dioniso será entoado ao longo da peça, nas mudanças de cena, nos silêncios ou como fundo em certos diálogos».

Um simples voltar de página surpreenderá ainda o leitor com a própria disposição gráfica do texto, repartido em duas colunas, encimadas por duas legendas "Vivos», Mortas». Reservada a acção aos intervenientes vivos, naturalmente, às duas mulheres mortas competirá uma série de comentários breves, paralelos à acção, que descobrem, sob as palavras ditas ou as atitudes tomadas, ocultas intenções ou as interrogações que desvendam o próprio paradoxo de cada alma. São, portanto, estas vozes do além uma espécie de eco da consciência, que lê e interpreta para além da superfície das palavras ou dos actos e inspira hesitações ou conflitos psicológicos.

Também este texto conheceu a experiência da encenação e representação, quando em 1993 foi levado à cena pela Comuna Teatro de Pesquisa, sob a direcção de João Mota.

Um tipo de análise cena a cena desconvém à criação livre de Hélia Correia. Talvez a valorização de certos fios temáticos ou de certas figuras se ajuste melhor ao efeito produzido pela peça. E o primeiro pensamento que parece impor-se é exactamente aquele que antagoniza as componentes masculina e feminina da acção, numa dicotomia paralela à oposição dos conceitos de nomos e physis. Naturalmente que este conflito era já claro em Sófocles, como S. Wiltshire ${ }^{1}$ sintetiza em palavras felizes: "Com uma mulher por antagonista, Sófocles cria, de forma ainda mais dramática, aquilo que ao público ateniense

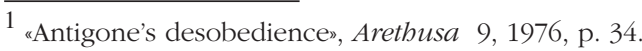


do séc. V pareceria um conflito entre dois níveis diversos de ser humano, de dois sistemas éticos totalmente descontínuos». Esta é uma polémica privilegiada por Hélia Correia e uma nota muito marcada, desde a abertura, pela intervenção do coro de Bacantes. Dioniso surge como o único poder divino da peça, representando a força da natureza e do instinto a que adere sem reservas a psicologia feminina. Dotada de uma natureza mais instintiva e primária nas suas reacções, a mulher procura no deus, vivo na pujança do Citéron, uma satisfação que a ordem social lhe recusa. Ansiosas de se deixarem possuir pela força renovadora da divindade, as mulheres afastam-se da convenção social, de Tebas e da lei. São assim as funções biológicas e escatológicas, traduzidas em palavras agressivas, aquelas com que o coro dá o tom físico e sensorial à actuação feminina na peça. Pela sua crueza importa fazer ouvir as bacantes: "Pelo fogo da língua, pelo sopro e contágio da língua. Pela boca, os buracos do corpo que nos ligam ao estrume e ao alimento. Os buracos do corpo onde entra o homem e escorrem as sangrias, por onde nos rebentam as crianças» (p. 17) ${ }^{2}$. Dioniso é despido de religiosidade, para encarnar a força viva da natureza que renova as espécies, que as mulheres aspiram na loucura do movimento circular da sua dança. Quando enfim possuídas e hesitantes ainda sobre o sentido do prazer que o rito lhes dá ("Será isto o amor?», pp. 18-19), o grito de liberdade que erguem aos céus é também o do repúdio pela cidade e suas peias: "Ah, que longe está Tebas, longe a lei. Longe os terraços, longe os leitos, oh!» (p. 19). Que reine o instinto que dá asas ("Dá-nos o gozo, ó deus, (...), faz-nos voar»), justificação única da existência («amanhã morreremos, e é preferível pensar que por ti, sim, valeu a pena»); a esse a morte, que apaga as almas, não emudece ("Fiquem uivos e trevas porque não há memória e a alma esquece, seja qual for o modo de existir»). Com este canto das ménades, a tradicional polémica sofocliana entre lei divina e humana recua, para dar lugar àquela outra tensão entre instinto natural e ordem social, que anima as Bacantes euripidianas. Uma imagem do

\footnotetext{
2 O texto de Hélia Correia é citado pela edição de Publicações Dom Quixote, Lisboa, 1991.
} 
mundo masculino desponta vagamente no termo deste canto: a do caos das praças saqueadas; mas mesmo da noção máscula do flagelo da guerra, que a dureza das palavras evoca, as mulheres parecem tirar o prazer da libertação e renovação. E um primeiro fosso se cava entre as duas faces da experiência da guerra, quando o caos, por milagre da leitura feminina, se torna magnífico e da imagem das praças saqueadas se extrai volúpia (p. 21), na expectativa do «rebentar novamente das primícias».

Criado este contexto para as tendências e para a actuação feminina, toda a atenção de Hélia se concentra sobre a figura de Antígona-mulher. Um conjunto de experiências vai definindo uma infância, uma adolescência, o sabor do exílio, um contorno de relações familiares, o sonho de um casamento, a aprendizagem e o crescimento de uma criatura humana, que se esbarra com a secura, a anormalidade, a insegurança, o vazio, até se tornar a presença incómoda e problemática que lembra um passado de desgraça e oferece a todos a face da desadaptação. Delineado o retrato, estamos diante da Antígona que se opõe à vontade soberana do rei, da família e da cidade. E essa não é a heroína, superiormente dobrada à força do dever para com os deuses ou para com os princípios superiores, solitária porque detentora de uma determinação desusada ou única ${ }^{3}$; nem tão pouco aquela filha de uma família maldita que mantém, para além dos crimes cometidos por cada um dos seus parentes, um respeito inquebrantável pela voz do sangue; a nova Antígona é o simples fruto de uma experiência frustrante, que lhe destrói hora a hora a alma, que a deixa solitária porque ressentida com tudo e com todos, e, por esse mesmo ódio, capaz de

\footnotetext{
3 A esta superioridade da heroína sofocliana não é, no entanto, estranho um certo excesso que levou alguns comentadores a acentuarem a culpa de Antígona. Para além da determinação que o cumprimento do dever lhe exige, a verdade é que a jovem, no dizer de M. Pulquério (Problemática da tragédia sofocliana, Coimbra, 1968, p. 36), "se embriaga com uma vaga perspectiva de martírio». Desta embriaguez nasce uma frieza, uma irredutibilidade, uma rigidez, medida pelas do seu opositor, Creonte, que concorrem para a profundidade do desastre. Também S. M. Adams («The Antigone of Sophocles", Phoenix 9, 1955, p. 48) acentua a falta de sophrosyne da heroína, demarcada desde o prólogo pelo contraste com Ismena.
} 
uma rebeldia inabalável. O que na Antígona sofocliana pareceu a alguns «uma fixação na família» ${ }^{4}$, no sentido de uma solidariedade constante para com os seus, é, na Perdição, a causa de uma malformação psicológica, que a isola e a torna detestada por todos. A própria Hélia Correia, ao comentar a personagem que criara, afirmava de forma expressiva: «Finalmente deixei de a tratar com cerimónia. Ela, que sempre fora a heroína a quem eu dedicara temor e gratidão pelo longe que estava dos meus dias, com as suas convicções e o seu atrevimento. Se alguma vez voltasse os olhos para mim, eu baixaria os meus, dizendo: "Non sum digna». Com aquela coragem que parecia tão simples, tinha-se colocado para sempre entre nós e as grandes atitudes. Até que a vim a conhecer ainda menina, ainda emudecida pelo terror, quando a tragédia se abateu sobre a família e ela se limitou a socorrer o pai, a ser o guia, o amparo daquele cego. Vi-a a chorar, sem fala. E, apesar de saber que anos mais tarde ela estaria transformada naquela personagem cuja estatura sempre me assustara, comecei a amá-la como se ama uma filha, devagarinho e a chamá-la para mim. E a sua tragédia era outra tragédia: uma ansiedade de rapariguinha. Vivia rodeada de mulheres, receando a velhice das mulheres. À distância, podia avistar o Cítero, ouvir os gritos das bacantes que dançavam na porcaria e na exterminação. E, como nesse tempo eu estive muito perto - tive-a por assim dizer, ao colo todas as noites - pude espreitar para o lado nunca exposto do seu coração de órfã. Limitei-me a escrever o que nele achei».

À procura dessa outra intimidade com Antígona, Hélia cria uma análise poliédrica, em que, face a face, a filha de Édipo se nos vai revelando. Da infância avultam duas memórias, a da Ama e a de uma cadelinha, que representam a aspiração de afecto e protecção de que depende o crescimento estável. Para o animal a criança volta-se como para a referência de todos os afectos: o objecto de amor constante, mesmo perante a secura do exílio (p. 23: «Durante todo o exílio, dava por mim a pensar nela, a querer-lhe bem»); o porto seguro

\footnotetext{
$\overline{4_{\text {Vide Adams, op. cit., p. }}} 50$.
} 
onde se quebram todos os temores, pelo toque simples de uma carícia por entre o gelo petrificante da solidão (p. 23: "À noite, no pavor, entre as covas das pedras, punha-me a lembrar dela. Via-a saltar, a querer chegar-me à cara»); a protecção certa, necessária à vida, que se receia perder como um arrimo indispensável (p. 23: "Então tinha receio de que a tratassem mal»). Mas este lado bom da Antígona-menina, que aspirava ao crescimento saudável, estava condenado à destruição; então a cadelinha desapareceu, por negligência da Ama. Lá de entre os mortos, as vozes ecoam agora para repor a verdade. Negligência não, propósito de matar, de aniquilar, sob a forma de um amor simples por uma cadelinha, a doçura de uma alma de criança. Porquê? - interrogase Antígona. "Não consegui compreender porquê». E a crueldade gratuita deste acto de destruição torna-se mais patente pela própria incerteza dos motivos: «Parece que me deu uma dentada. Ou coisa assim» (p. 24), justifica vagamente o destino assassino. Para além da cadela, a Ama traz a lembrança do calor da casa, da protecção do ninho indispensável à cria extraviada nos caminhos da ausência: o conforto de um prato de comida, a segurança feliz que dá um colo amigo. Encarna esta mulher o símbolo materno, a presença diferida da mãe, que por ser diferida é falsa; é verdade que as funções do seu cargo as cumpriu com escrúpulo: «Criei-te. Não dormi para te embalar. Mamaste o leite do meu peito» (p. 24). Mas faltou o vínculo congénito, onde passou a reinar a própria frustração: "Aos meus filhos, não pude fazer isso. Jocasta não os quis ali por perto» (p. 24). E se a alegria infantil logrou, por vezes, quebrar ressentimentos e estimular à brincadeira sã e espontânea:- «Eu era muito jovem, nesse tempo. E punha-me a dançar contigo ao colo. (...) Rias muito. Puxavas-me pelo fato. Eu segurava-te nas mãos e dava voltas contigo assim, no ar, como se esvoaçasses» (p. 25) -, o ciúme da mãe verdadeira não deixou nunca que a espontaneidade saudável da alegria perdurasse, também ela vítima da deturpação dos sentimentos: "Jocasta enfurecia-se com isso" (p. 25). Com o curso do tempo, esta Ama ganhará os contornos de uma verdadeira encarnação do Destino, que parece disposto a seguir Antígona sem tréguas, que é vulnerável às animosi- 
dades do exterior, que espicaça na sua protegida os lados mais negros do seu carácter, que só sente cumprida a sua missão quando chega a hora derradeira. Ainda entre os mortos ela se manterá atenta, para se garantir, até ao baixar do pano, do cumprimento pleno do seu papel.

Veio então o exílio, que se impôs como uma ruptura de tudo que ainda era alegria e segurança. A brecha na estabilidade do palácio abriu-se por obra de Édipo, assustado, inseguro, como que a atrair a peste sobre a casa. Do temor por tantos crimes acumulados sobreveio a acusação, a sentença e o afastamento. Ao lado do fracasso que representou a actuação maternal dentro da família, a falta de ternura que haveria de ter cercado uma infância feliz, surge agora outro insucesso, o da figura do pai, cujo papel de força e protecção se gorou também. As honras que o cercaram como o vencedor da Esfinge, o prémio do trono e da mão da rainha devido ao herói, o cortejo triunfal que o acompanhou na entrada em Tebas são já apenas uma memória distante e fugidia. De certo resta a lembrança de um leve tremor de mãos, a anunciar a derrota que o destino reservava ao condenado. Nessa hora maldita, das mãos que cercavam o rei, erguidas em torrentes de aplausos, só uma restou, aquela que uma menina frágil, tomada de devoção filial, lhe estendeu: "E depois, numa volta do destino, quando todos os males se abateram sobre ele, ninguém, a não ser eu, lhe foi estender a mão» (p. 26). Mas não era mais uma menina esta que cumpria um dever, guiada pela estrela brilhante da vingança. Porque esta outra Antígona não fala de amor, mas de ódio, os deuses que venera são terríveis, hediondos, violentos, mas os únicos que lhe deram protecção e ânimo para sobreviver. Mais afoita, a heroína morta arranca da memória a imagem pestilenta do velho cego, do asco que a presença do doente lhe causava: "Recordo-me tão bem das noites do exílio. Os olhos do meu pai deitavam pus. Detestava beijá-lo. Escondia-me até que me passassem os vómitos» (p. 27). É este o primeiro contacto directo que Antígona tem com o universo masculino: o da derrota moral e física, que cria desprotecção e nojo. Mas esse mundo que se lhe abria fora da reserva da casa, gravou-lhe outras imagens indeléveis: "Aquele suor dos homens. O vinho que escorria 
pelas barbas doiradas» (p. 27); o da brutalidade a avultar sobre um vago ruído de heroísmo que não passa de uma simples ilusão: «Eles cofiam a barba e ficam pálidos sob o peso do vinho, por um pequeno instante. Então eu oiço qualquer coisa dentro deles, um tropel de cavalos, um clamor. É o sangue a cantar na lembrança das guerras» (p. 28). Uma solidão cruel torna-se a companheira mais fiel desta jovem em formação, em casa como nos caminhos imprevisíveis da vida. O sofrimento junto do pai exilado faz calar dever e afecto, para dar lugar a uma tremenda reacção física perante o pus nojento da desgraça.

Por isso a adolescente que regressa à casa e à família, que se confronta com o mundo da normalidade, é uma estranha, que ninguém mais reconhece, por trás do peso de duras lembranças, incapaz de alijar a carga de uma experiência distorcida, para voltar a sorrir como qualquer rapariga da sua idade. Como recuperar, depois de ter sido «bicho» (p. 27), as cores doces da juventude? "Assim te ouvisse eu rir e gracejar, e te visse partir para a ribeira a tomar banho, muito de manhã, e regressar corada e enfeitada de juncos, tal como a tua irmã e as outras raparigas» (p. 27). Este suspiro de Eurídice não obtém mais sucesso do que o dedo condenatório apontado pela Ama: "Que havia ela de dizer-te, a ti? Somente que incomodas, que acordas más memórias com os teus ares de vítima. Também eu já estou farta. Fatigas toda a gente» (p. 29). Haverá água que lave tantas mágoas e tanta sujidade a manchar alma e corpo? "Cheiras mal» - é a condenação desta Antígona que regressa para incomodar todos os que lhe são próximos, cada um de sua forma.

Hémon surge na vida de Antígona como um pretendente apaixonado, mas também ele incapaz de trazer ao seu amor uma gota de sentimento. É o instinto que pondera nas pretensões deste homem, que não desmente a brutalidade masculina com que a jovem convivera no exílio. São os olhos quem comanda a paixão de Hémon, e uma atracção física e irracional que tudo ousa: «Hás-de ser minha esposa. Ou minha concubina. Por lei ou pela força. Estou determinado a possuir-te. (...) - Eras capaz de me obrigar, a mal? - Era capaz de tudo para te ter (p. 31). A relação com que ambos sonham é fogosa, despida de preconceitos, 
vivida na aventura e na distância do sonho. Instável, numa palavra, cheia de imprevistos. Ao recordá-la, das margens distantes do além, Antígona acentua-lhe os contornos fugazes, incertos, que lhe deixaram uma lembrança apagada: "Acho que fui feliz com Hémon. E no entanto não me lembro do seu rosto. Nem já da sua voz» (p. 32). Nem tão pouco Hémon é capaz de desfazer na amada a imagem da fraqueza masculina, provada nos temores de seu pai no exercício do poder, ou no abatimento de guerreiros dominados pelos vapores do álcool, na obscuridade de tabernas. Este é um príncipe que ocupa os dias a espiar as moças no rio, a satisfazer instintos, do poder esperando apenas a oportunidade para se assenhorear de um trono que outros, por um louco fratricídio, lhe deixaram vago.

No entanto, desta aventura colheu a filha de Édipo um resquício de alegria, que, mesmo esse, lhe não foi consentido. Cada gesto de Antígona, neste regresso aos seus, se sente como incómodo e rejeitado. Ainda há pouco a sua imagem de tormento e memória de um passado sofredor incomodava todos; agora é o sorriso de alegria, que o amor de Hémon provocou, que abre feridas, na irmã, prometida ao mesmo noivo, que se sente «despeitada, ofendida pela humilhação» (p. 33). Antígona faz um esforço sério em nome da felicidade, quer aprender, com a experiência das mais velhas, a arte de ser ditosa; outras tantas punhaladas sobre Isménia, que, "como se lhe doesse alguma coisa, se dobrava sobre si própria» (p. 33). Em nome de quê mais este conflito? Afinal que desengano o da felicidade prometida. À falta de convívio com amigas da sua idade, com quem aprenderia a vida sob uma capa de sonho que só aos poucos desvenda o desengano, Antígona, também decepada de amizades, tem de refugiar-se na decepção vivida das mais velhas. Forma esta dolorosa de aprender a viver sem mesmo o estímulo de fantasias juvenis. Tristonha, Eurídice cumpre o seu papel maternal de desvendar, à curiosidade da jovem, a eterna rotina que a espera, tão pouco consentânea com a ânsia do seu coração e do seu corpo de mulher: «É uma sombra. Estende a mão e não agarras nada. Fica uma vida, filha, entre os teares, os armazéns e a lareira. Entre o sangue dos 
meses e o sangue dos partos. A governar entre criadas» (p. 34). Depois o enfado do marido, que procura numa escrava ou concubina, mesmo num rapazinho, o despertar rebelde de uma vaga emoção. Porque à mulher, apesar de deitado ao seu lado, o homem não dedica mais do que a atenção de um braço distraído, enquanto o pensamento lhe mergulha na voragem de mil aventuras e expedições de onde tira o sabor másculo da vitória. À desilusão, a que o divórcio inevitável entre os dois sexos conduz, responde Dioniso, a salvação que o desencanto feminino busca, no desejo de responder aos anseios inevitáveis da natureza. É este o refúgio secreto da mulher, confrontada com a engrenagem de uma rotina, montada pelos homens em sociedade, que lhe esmaga a vida.

Assim se completa na Perdição uma espécie de ciclo dionisíaco e feminino. O mesmo deus que as bacantes celebravam como expressão dos seus anseios naturais, acaba de penetrar na vida de Antígona, agora detentora da experiência precoce de uma mulher adulta; experiência por seu mal conhecida antes do tempo, antes que a ilusão dos verdes anos, que não viveu, pudesse proteger-lhe o coração com a memória de dias felizes, quando à porta batesse, fatal, o desengano. O ser criado que se nos oferece é uma criatura deturpada, sem correcção possível, que só um regresso ao ponto de partida poderia alterar. Essa verdade reconhece-a Eurídice: «Se eu pudesse fazer-te nascer de novo. Criar-te devagar. Doer-me e orgulhar-me de te ver ganhar corpo e ideia de mulher. E amar-te» (p. 38).

Cabe a Tirésias fazer a passagem do feminino ao masculino, com o seu comentário sobre a guerra, como uma metamorfose do pó que se ergue das patas dos cavalos em pasta de sangue. Coroas e lucros são o prémio do perigo, neste mundo de volúpia e estonteamento, "que só a eles é dado conhecer» (p. 41). Discretamente delineado antes, o universo masculino ganha agora uma dimensão prioritária. É este o momento de fazer avultar a figura de Creonte como seu paradigma. Pertence-lhe a dignidade régia, que se exprime no esplendor convencional do manto, e também a preocupação de calar toda a contestação ou concorrência ao seu poder. Escapa-lhe no entanto o controle 
sobre a cidade e a família. A guerra deixa-o impotente, a família melhor fora que morresse para o libertar da difícil tarefa de a comandar. Na sua perspectiva, a sociedade, para ser coesa e tranquila, numa submissão passiva à sua autoridade, não comporta sentimento nem condicionamentos familiares. Só depois de silenciadas pela morte as paixões excessivas que condenaram os Labdácidas, pode enfim Creonte comprazer-se num comando tranquilo de Tebas. Nomos impõe-se nesta nova visão do mundo como um factor racional e antagónico de instinto, natureza ou paixão, responsável por uma concepção de paraíso terreal que a realidade não deixa sobreviver. Que espera o povo do seu governante? «Prosperidade e paz. E, é claro, um exército de luxo que brilhe ao longe e assuste os inimigos a ponto de os desanimar do combate. - Uma terra onde corra leite e mel. E se rebentem os tonéis de vinho nas manhãs consagradas a Dioniso. Onde as mulheres se esqueçam do delírio que agora as faz errar pelo Cítero, como cabras à lua. Onde a história da Esfinge e destes mortos seja contada finalmente como história, com o imenso alívio que isso dá»(p. 42). Só que este éden despido de emoção está condenado ao fracasso, em breve o aborrecimento vai chegar acompanhado da contestação. Como Édipo recebera os aplausos devidos ao herói com uma leve tremura de mãos, Creonte aceita o poder com uma feroz dor de barriga, que nenhuma infusão conseguiu calar. Um temor constante de ameaça envenena essa ordem social que o homem fantasia.

Pela boca do soldado chega a notícia da desobediência, o golpe temido na autoridade máscula. Como em Sófocles, Antígona é a voz solitária e dissonante na contestação à arbitrariedade régia. Todos os cidadãos aprovam o édito. Por isso as atenções convergem para ela e do seu acto cada um proporá uma interpretação. Quem será, de facto, a heroína Antígona? Apenas aquilo que cada um quiser ver nela, a soma de todas as razões que a terão demovido ao seu acto. Acto esse em que se projecta cada faceta daquela alma que vimos crescer diante dos nossos olhos, sofredora, vazia, deturpada. Não é no mundo do transcendente que se irá procurar a justificação para o acto de Antígona, mas 
dentro das profundezas desta mulher estranha, que cada um lê a seu modo. Longe estamos da segurança e grandeza de uma confrontação entre duas vontades fortes e contrárias, à maneira sofocliana; o diálogo que agora se instala é uma espécie de avaliação psicológica, que tende sobretudo a aprofundar motivos e secretas razões da alma.

Isménia afeita à ordem e à convenção social identifica-se mais com o ramo da família onde Creonte pondera, do que com aquele a que pertence, responsável por todas as perturbações na casa dos Labdácidas, fonte inesgotável de todas as destruições. Para o seu coração ressentido pela concorrência de Antígona no amor de Hémon, o acto da irmã manifesta loucura, o desejo insaciável de se impor pelo escândalo, de atrair sobre a sua pessoa todas as atenções: "Aí está ela como sempre quis: no centro dos olhares e arvorando um ligeiro sorriso de desprezo» (p. 47); perdoar-lhe será frustrar-lhe o objectivo, reduzi-la ao anonimato, a mais dura de todas as punições: «Perdoa-lhe, meu tio, estraga-lhe o efeito de espectáculo, agirá como o mais duradouro castigo» (p. 48). Entre as duas irmãs nada mais existiu do que uma rivalidade inconsciente e essencial, cavada pela própria natureza que as moldou tão diversas e tão profundamente distantes. Por isso, ao recordar Isménia no além, Antígona só pode interrogar-se sem encontrar resposta para a sua perplexidade: "Que senti por Isménia? Tu lembras-te de Isménia?» (p. 48).

Também Eurídice implora para Antígona o perdão real, mas por simpatia, decerto por um vago sentimento de responsabilidade pelo produto falhado do seu carinho quase maternal. Procura elevar os motivos de Antígona, a piedade e a coragem que a levaram a sacrificar-se pela memória do irmão, a noção de dever a que não quis eximir-se, embora incorresse em desvario. Nessa rebeldia, percebe Eurídice uma contestação retardada de criança que não teve, em tempo próprio, oportunidade de fazer valer uma natural teimosia: "Ela não conheceu a infância descuidada. Isto foi de algum modo a sua brincadeira» (p. 49).

O criado, que talvez ecoe uma opinião popular e certamente masculina, vê no acto de Antígona apenas o resultado de uma ordem politicamente errada. 
Se Creonte não pretendesse impor-se pela letra da lei, talvez a contestação não tivesse surgido, por não ser previsível o interesse de ninguém pelo destino do cadáver de um traidor. Em sintonia total com esta perspectiva, o rei reconhece mesmo que a ordem teve uma finalidade demagógica, a de manifestar a adesão da vontade popular à do seu chefe; apenas, como todos os golpes políticos, comportava riscos imprevisíveis que a perspicácia real não soube prevenir. O que poderá querer Antígona com a sua oposição? Mostrar-lhe ódio? Ofendê-lo? Ou não será a sua atitude simples histeria de um espírito inseguro, a precisar de «sofrer exorcismos e algumas chicotadas para expulsar os demónios que o habitam?» (p. 48). Seja como for, a verdade é que razões de família e de imponderação feminina se misturaram com interesses políticos para agravar a situação: "Pois não entendes que por ser minha sobrinha ainda mais as coisas se complicam? Seria já difícil perdoar a um estranho quando o mais importante neste grave momento é fazer prova de uma autoridade inflexível!» (p. 49).

Por fim a própria Antígona parece em dificuldade para se justificar. São mais ambíguas do que quaisquer outras as suas palavras. O seu acto não passou "de qualquer coisa que tinha de ser feita» (p. 47); como outrora por seu pai, Édipo, um vago sentimento de piedade pelo irmão, a que não é estranha uma tremenda repugnância física, a motivou: «Assim agora me chamou o corpo já verde e malcheiroso de Polinices. Um pobre corpo de homem que grita pela cova, que grita pela terra para se desfazer» (p. 47). A solidariedade tardia de Eurídice aborrece-a, talvez por lhe saber a uma reparação inoportuna e inútil: «Não te esforces por me compreender nem por diminuir a minha falta. O afecto e a ternura que me tens dedicado só me incomodam» (p. 49). Habituada à solidão e à frieza, a jovem recusa uma intromissão de sentimento que não se ajusta agora à sua experiência e tem o sabor da hipocrisia e do remorso. Do Hades, a sombra de Antígona não renega esta reacção contra a solidariedade familiar: «Penso mais em Eurídice. Irritava-me com as suas maneiras maternais» (p. 49). Por fim, ao recusar a hesitação de Creonte, incapaz de condenar, apesar de tudo, alguém do seu sangue, Antígona parece completar o retrato de si própria; 
não muito segura das suas convicções, mas apesar de tudo sensível ao prazer da solidão e do perigo, a que a vida, sem interrupções, a habituou. É assim que a Ama interpreta o desfecho desta ponderação: "Aí está Antígona como sempre quis estar. Só e ameaçada, num campo de batalha» (p. 50).

Avaliadas as razões múltiplas que justificam o choque entre Creonte, rei, homem e familiar, e Antígona, jovem solitária, ferida, revoltada, sensível, apesar de tudo, à voz do sangue, todos procuram para o conflito uma solução ${ }^{5}$. Em nome de quê se poderá abalar a vontade de Antígona? De uma harmonia neutra que agrada ao espírito fraco de Isménia? Do desejo de salvar da extinção total uma família quase destruída? Em paga do amor de Eurídice, mais mãe do que a própria mãe? Apenas a Ama, como sempre na representação do destino, se opõe ao coro de vozes que apelam à salvação: «O caminho de volta apagou-se debaixo dos seus pés» (p. 52). Sobre ela Antígona ergue a voz, para não deixar ao destino apenas a solução da sua existência. Numa afirmação de vontade própria, que lhe preserva alguma grandeza ou veromisilhança psicológica, a jovem reivindica: «Que pensais vós de mim? Tão fraca serei eu nas minhas decisões?» (p. 52). Mas a Eurídice não escapa a firmeza dessa força aniquiladora que em todo o tempo condicionou a existência de uma alma: "És obra dela, Antígona. Usou-te e vai-te perder. Como, porquê e para quê, não sei» (p. 52). A própria vítima o reconhece do além: «Seguiste-me na morte para teres a certeza de que eu não recuava» (p. 53). Vigilante, sedutora como um canto de sereia, é ela quem cala os temores de Antígona e a força à opção pela morte. Ao medo, junta-se a volúpia do contacto com um mundo desconhecido, que se parece com o temor da virgem perante a iminência das núpcias, ou mesmo com a atracção das bacantes pelo deus risonho e feio que as endoidece: «Um susto,

\footnotetext{
5 Em Sófocles a ideia de salvar Antígona é equacionada face a sinais manifestos do desagrado dos deuses. Entre os homens, a ideia de que o conflito não é pessoal, mas de princípios, de interesses ou de autoridade, exclui a possibilidade de se avaliar a questão em relação à vítima em si; Creonte nada tem pessoalmente contra Antígona, mas contra tudo quanto de insubmissão ou de revolta o seu acto significa. A perspectiva pessoal que Hélia Correia acentua coloca o problema da salvação num plano inteiramente humano e individual. A ponderação que a situação sugere convém a um debate de família.
} 
um terror pânico, uma luz deslumbrante que dói, antes que venha a perda da consciência» (p. 54). «Isso é morrer» (p. 54) - grita a Ama, ou viver, contrapõe a experiência báquica de Eurídice. Outra é a sugestão masculina para a salvação de Antígona, que a voz de Hémon propõe. O jogo de sentimentos ou o apelo à emotividade está dela ausente, importa manter as aparências de força e ordem. Nenhuma das partes é chamada a abdicar, ambas manterão um exterior de persistência; apenas nos bastidores tudo se arranjará para que a vítima seja salva. Negociado em comum o golpe, a perpetrar por um terceiro interveniente, ninguém sairá malferido ou desprestigiado desta solução.

Somente para Antígona não há salvação, essa já não depende da vontade dos que a cercam mas da sua personalidade. Para aquela criatura que a vida fez diferente e desadaptada não há lugar neste mundo, a própria excepção a condena: «Já nenhum homem a satisfaria» - reconhece a Ama. E, em sintonia, Antígona confirma: «Já nenhum homem. E nenhuma casa. E nenhuma ninhada de filhos para criar. Dias depois de dias, dias sempre. Até envelhecer. Com a ternura e os ressentimentos a flutuar sem destino dentro do coração. Com as entranhas ardendo cada vez mais sozinhas» (p. 56). Mas se o nomos não quadra com os seus anseios, a verdade é que a própria physis feminina de Antígona é diversa do padrão de que Eurídice, a voz da experiência, dá o paradigma. Nem na fuga que Dioniso patrocina vê a jovem amada de Hémon uma promessa de equilíbrio ou de compensação: "Não terei de fugir para as clareiras e espojar-me no chão para gozar longe de ti. Como ela goza longe de Creonte» (p. 56). Despida de todo o traço humano, inspirado em motivos masculinos ou femininos, o que resta de Antígona é o monstro, irreconhecível para os homens e portanto condenado à destruição. Todas as vozes se erguem unânimes na condenação: "Tinha tudo trocado na cabeça»; "Vigiava de noite, dormia de dia»; "Não respeitava nada» (p. 57). Até a vítima se interroga em dorida conclusão: «Eu não conseguiria viver com eles, suportar aquela paz ...?» (p. 57).

Já diluída na sombra do além, para sempre perdida para os vivos ela que não pôde viver, um último pensamento de Antígona vai para a cadelita - "Ainda 
me lembro dela. Da minha cadelita ...» (p. 57) - como uma vaga promessa de normalidade e humanismo que o destino - essa Ama cruel - matou à partida.

\section{Bibliografia}

\section{Textos}

Hélia Correia, Perdição. Exercício sobre Antígona, Lisboa, 1991.

A. C. Pearson, Sophoclis fabulae, Oxford University Press, reimpr. 1961.

M. H. Rocha Pereira, Sófocles. Antígona, versão portuguesa, Coimbra, 1984.

\section{Estudos}

S. M. Adams, «The Antigone of Sophocles», Phoenix 9, 1955, pp. 47-62.

C. M. Bowra, Sophoclean tragedy, Oxford, ${ }^{7} 1965$.

W. M. Calder III, "Sophokles» political tragedy, Antigone»,GRBS 9, 1968, pp. 389-407.

D. A. Hester, "Sophocles the unphilosophical. A study in the Antigone", Mnemosyne 24, 1971, pp. 11-59.

G. M. Kirkwood, A study of Sophoclean drama, Cornell University Press, 1958.

B. M. W. Knox, The heroic temper, Berkeley and Los Angeles, ${ }^{2} 1966$.

M. McCall, "Divine and human action in Sophocles: the two burials of the Antigone", YClS 22, 1972, pp. 103-117.

M. Pulquério, Problemática da tragédia sofocliana, Coimbra, 1968.

V. R. Rosivach, "On Creon, Antigone and not buryind the dead", RhM 126, 1983, pp. 193-211.

C. P. Segal, "Sophocles, praise of man and conflicts of the Antigone», in Sophocles, a collection of critical essays, ed. Th. Woodard, Englewood Cliffs, 1966, pp. 62-85.

S. F. Wiltshire, «Antigone's desobedience», Arethusa 9, 1976, pp. $29-36$. 



\section{Série}

\section{Documentos}

Imprensa da Universidade de Coimbra

Coimbra University Press

2006

- $\mathrm{U}$

C • 